Бунчак О. М.

\title{
УДК 633.34:631.879
}

УРОЖАЙНІСТЬ І ЯКІСНІ ПОКАЗНИКИ ЗЕРНА СОЇ ЗАЛЕЖНО ВІД ЗАСТОСУВАННЯ ОРГАНІЧНИХ ДОБРИВ ІЗ ЗБАЛАНСОВАНИМ УМІСТОМ ТРИВАЛЕНТНОГО ХРОМУ

О. М. БУНЧАК, кандидат сільськогосподарських наук, докторант Подільський державний аграрно-технічний університет

E-mail: vermos2011@ukr.net

Анотація.

результати впливу органічних добрив «Біопроферм», «Біоактив» та «Біохром» із збалансованим умістом тривалентного хрому виготовлених методами відповідно біологічної ферментаиіï та кавітацї на урожайність та якісні показники зерна сої сорту Устя в умовах Західного Лісостепу.

Метою дослідження було вивчити їх вплив на ріст і розвиток рослин та урожайність сої сорту Устя в умовах Західного Лісостепу.

Польові $i$ лабораторні дослідження виконано в умовах західного Лісостепу упродовж 2013-2016 рр. на дослідному полі Подільського державного аграрнотехнічного університету. Ірунт дослідної ділянки - чорнозем типовий важкосуглинкового гранулометричного складу.

Агротехніка вирошування сої загальноприйнята для умов західного Лісостепу України. Супутні дослідження $i$ спостереження виконано за загальноприйнятими методиками.

Встановлено, щуо у всіх варіантах, де вносилися органічні добрива «Біоактив», «Біопроферм» за рахунок покрашення агрофізичних, агрохімічних властивостей трунту та його біологічнӧ̈ активності покрашувався поживний $i$ водний режим трунту, щзо забезпечило збільшенню польової схожості на 6,7-7,1\% та виживання рослин на 4,4-4,6\%, висота рослин зросла на 5,9-8, 2 см порівняно з контролем.

Найбільша площуа листкової поверхні рослин сої у фазу кінещзь извітіння - 41,6 тис.м²/га або на 8,9 тис.м ${ }^{2} / г$ більше контролю була на варіанті, де вносили під основний обробіток трунту $10 \quad \mathrm{~m} / 2 \mathrm{a}$ органічного добрива «Біопроферм» із збалансованим умістом тривалентного хрому та обприскували рослини сої під час вегетації рідким органічним добривом «Біохром» - 5 л/га. На изьому варіанті фотосинтетичний потениіал становив 2,384 млн.м ${ }^{2}$ діб/га або на 0,348 млн.м ${ }^{2}$ діб/га більше контролю, чиста продуктивність фотосинтезу у фазу извітіння становила 10,52 2/ $\mathrm{m}^{2}$ на добу або на 0,84 г/ $\mathrm{M}^{2}$ на добу більше контролю.

Досліджено, щуо органічні добрива, виготовлені за новітніми технологіями, в усі роки досліджень впливали на підвищення врожайності сої. Так, у варіанті, де під зяблеву оранку вносили органічні добрива «Біопроферм» у дозі 10 $\mathrm{m} / 2 a$ та виконували позакореневе 
Бунчак О. М.

підживлення рідким органічним добривом «Біохром» (5 л/га), в середньому за роки досліджень урожайність була на 1,25 m/2a більше, ніж у контролі $i$ на 0,18 m/га більше, ніж у варіанті 3 внесенням органічного добрива

\section{Актуальність.}

Перед

аграрною наукою сьогодні стоять надзвичайно складні завдання розробити i впровадити-__ виробництво технологічні заходи щодо вирощування сільськогосподарських культур 3 необхідним умістом у продукції макро- і мікроелементів, що сприятиме не тільки підвищенню врожайності культур, але й поліпшенню якості продукції. Такі завдання важливе значення мають i для формування збалансованого раціону годівлі тварин i повноцінного харчування людей.

В останні роки чільне місце серед мікро-елементів посідає тривалентний хром, який є одним i3 необхідних елементів у системі повноцінного росту й розвитку рослин, харчування людей і годівлі тварин.

Передусім

можна стверджувати, що досягається поставлена мета за умови, якщо продукція для буде вирощена на грунтах, де вносилися органічні добрива із збалансованим умістом тривалентного хрому [1].

Аналіз останніх досліджень і публікацій. Iз наукових джерел
«Біоактив» y дозі $10 \mathrm{~m} / 2 a \mathrm{ma}$ обприскуванням рідким органічним добривом «Біохром» в дозі 5 л/га nid час вегетації рослин культури.

Ключові слова: соя, picm $i$ розвиток рослин, урожайність, якість зерна

відомо, що-у невеликій кількості тривалентний хром-_є__важливим мікроелементом для росту i розвитку рослин та___необхідним для-_організму-_юдини-_і тварин. Вивченню дії $\mathrm{Cr}$ (III)__присвячено ряд наукових праць, зокрема, виконаних упродовж_—__ _вох останніх десятиріч_—_(Л._І Сологубом, P._Я. Іскрою, R._A. Andersonom та іншими) $[2,3,4,5,6]$.

Хром (III) є найбільш стійким i утворює стабільні сполуки в грунті за $\mathrm{pH}>$ 5,5. Тому окиснення $\mathrm{Cr}(\mathrm{III})$ не відбувається в організмі тварин і рослин.

I3

результатів експериментальних___досліджень, проведених упродовж останніх десятирічдесятирічь, випливає, що надходження тривалентного хрому__до організму має важливе значення___для___ підтримання фізіологічного__рівня глюкози__в крові__та метаболізму__вуглеводів, білків__i__ліпідів. У тривалентній формі хром перебуває у більшості продуктів i рослинних кормів, а також у___харчових добавках, преміксах, які використовують для годівлі тварин $[3,4,5]$. 
Бунчак О. М.

Тому важливо управляти продуційними процесами у грунті таким чином, щоб уміст тривалентного хрому був збалансованим у природному ланцюгу: грунт - рослина тварина - людина.

Узагальнені нами літературні дані свідчать про актуальність досліджень сполук тривалентного хрому в технологіях вирощування сільськогосподарських культур, зокрема в технології вирощування coï.

A тому, щоб збільшити урожайність сої із отриманням в зерні необхідної кількості $\mathrm{Cr}^{+3}$ виняткове значення мають агрозаходи, які спрямовані на покращення фотосинтетичної діяльності їх. Такими агрозаходами, $\epsilon$ застосування в системі удобрення органічних добрив із збалансованим умістом $\mathrm{Cr}^{+3}$,__виготовлених за новітніми технологіями [7].

Мета досліджень. Метою дослідження було вивчити вплив органічних добрив виготовлених за новітніми технологіями на ріст $і$ розвиток рослин та урожайність сої сорту Устя в умовах Західного Лісостепу.

\section{Матеріал і методика.} Польові і лабораторні дослідження виконано в умовах західного Лісостепу упродовж 2013-2016 рр. на дослідному полі Подільського державного аграрно-технічного університету. Ірунт дослідної ділянки - чорнозем типовий важкосуглинкового

гранулометричного складу, характеризується такими агрохімічними показниками: $\mathrm{pH}$ 6,5-6,8, уміст гумусу (за Тюріним) - 4,12-4,34 \%, забезпечення азоту що легко гідролізується (за Корнфільдом) - 116-124 мг/кг рухомого фосфору (за Чиріковим) - 86-91 мг/кг, обмінного калію (за Чиріковим) - 127-168 мг/кг грунту.

Органічне добриво «Біоактив» виготовляється по запатентованій нами технології із органічних відходів (пташиний послід, ставковий мул, тирса) методом прискореної біологічної ферментації. По ефективності 1 тонна «Біоактиву» рівнознчна 8-10 тонам традиційних органічних добрив (гній, пташиний послід, торфокомпостним) [7].

Органічне

добриво «Біопроферм» із збалансованим умістом $\mathrm{Cr}^{+3}$ виробляється iз органічних відходів шкіряного виробництва (міздра, осад очисних споруд + 8-10\% тирси) - містить загального азоту - 2,7 \%, фосфору - 3,5 \%, калію - 1,6 \% та 540 мг/кг $\mathrm{Cr}^{+3}$ методом прискореної біологічної ферментації [8].

Рідке органічне добриво «Біохром» виготовляється iз органічного добрива «Біопроферм» методом кавітації, містить гумінові речовини, 
Бунчак О. М.

фульвокислоти, фітогормони, макро і мікроелементи та 5,4 мг/л тривалентного хрому.

У досліді вивчали вплив органічного добрива "Біопроферм" (уміст $\mathrm{Cr}^{+3} 540$ мг/кг) та регулятора росту рослин "Біохром" (уміст $\mathrm{Cr}^{+3}$ 5,4 мг/л), отриманих за розробленою i запатентованою нами технологією, на ріст i розвиток рослин та продуктивність сої сорту Устя. Органічні добрива “Біопроферм" і “Біоактив" та мінеральні добрива $\left(\mathrm{N}_{120} \mathrm{P}_{80} \mathrm{~K}_{80}\right)$ вносили під основний обробіток грунту, “Біохром" - під час вегетації сої сорту Устя.

Агротехніка вирощування сої загальноприйнята для умов західного Лісостепу України. Супутні дослідження і спостереження_—__ виконано за загальноприйнятими методиками [9].

Результати дослідження та ïx обговорення. Соя - найдавніша і найпоширеніша культура__з усіх зернобобових культур у світі.__У насінні сої міститься 30-52 \% білка, 18-23 \% жиру, 20-30 \% вуглеводів, 5-7 \% клітковини, значна кількість ферментів, вітамінів, мінеральних та органічних речовин. Вона належить до стратегічних культур і задовольняє потребу в висококалорійних кормах для тварин і птиці та потреби людини в рослинному білку і олії [10]. Однак за останні роки у більшості господарств України, врожайність iii залишається низькою - 1,7-2,1 т/га. В той же час в Державний реєстр занесені вітчизняні та зарубіжні сорти сої 3 продуктивність 3,5-5,5 т/га.

Вирішити проблему збільшення урожайності сої можна за рахунок внесення органічних добрив виготовлених методом біологічної ферментації.

Відомо, що найвищі врожаї сільськогосподарських культур 3 високими якісними показниками можна отримати у посівах 3 оптимальною густотою стояння та площею листків, оптимальним процесом iii формування i структурою. Інтенсивність росту листкової поверхні та формування високого фотосинтетичного потенціалу листкової поверхні, значною мірою залежать від обгрунтованості

системи удобрення із внесенням органічних добрив «Біоактив» та «Біопроферм», які забезпечують тривалішу роботу листкового апарату.

Нашими дослідженнями встановлено, що органічні добрива виготовлені за новітніми технологіями значно впливали на густоту стояння рослин та продуктивність фотосинтезу сої сорту Устя (табл. 1). 
Бунчак О. М.

Таблннң 1. Густота стояння рослин та продуктивність фотосинтезу сої сорту Устя залежно від застосування органічних добрив виготовлених за новітніми технологіями (сер. 2013-2016 рр.)

\begin{tabular}{|c|c|c|c|c|c|c|}
\hline $\begin{array}{l}\text { № } \\
\Pi / \Pi\end{array}$ & Варіант & 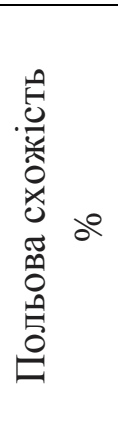 & 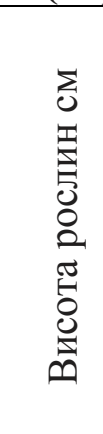 & 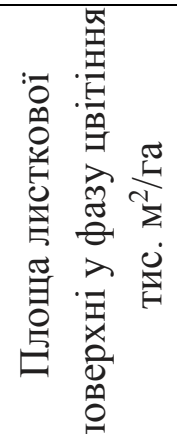 & 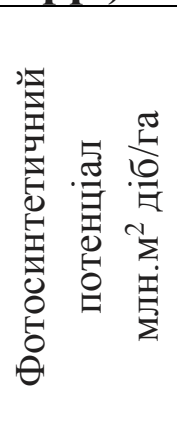 & 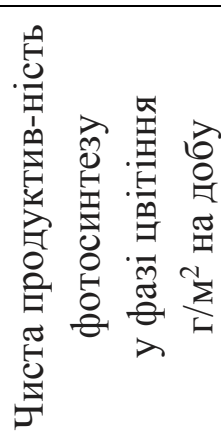 \\
\hline 1 & Без добрив - контроль & 80,7 & 87,2 & 32,7 & 2,036 & 9,68 \\
\hline 2 & Внесення $\mathrm{N}_{120} \mathrm{P}_{80} \mathrm{~K}_{80}$ & 84,9 & 90,8 & 39,3 & 2,258 & 10,15 \\
\hline 3 & $\begin{array}{c}\text { Внесення } \mathrm{N}_{120} \mathrm{P}_{80} \mathrm{~K}_{80}+\text { «Біохром» } \\
-5 \text { л/га }\end{array}$ & 85,2 & 91,4 & 39,7 & 2,270 & 10,17 \\
\hline 4 & Внесення «Біоактив»-10 т/га & 87,4 & 93,1 & 40,1 & 2,293 & 10,26 \\
\hline 5 & $\begin{array}{c}\text { Внесення «Біоактив» - } 10 \text { т/га }+ \\
\text { «Біохром» }-5 \text { л/га }\end{array}$ & 87,6 & 94,7 & 41,5 & 2,335 & 10,43 \\
\hline 6 & $\begin{array}{c}\text { Внесення «Біопроферм»- } \\
10 \text { т/га }\end{array}$ & 87,5 & 93,6 & 40,8 & 2,314 & 10,34 \\
\hline 7 & $\begin{array}{c}\text { Внесення «Біопроферм»- } \\
10 \text { т/га }+\ll \text { Біохром» }- \\
5 \text { л/га }\end{array}$ & 87,8 & 95,4 & 41,6 & 2,384 & 10,52 \\
\hline & $\mathrm{HIP}_{05}$ & 0,9 & 4,8 & 2,1 & 0,13 & 0,07 \\
\hline
\end{tabular}

Встановлено, що у всіх варіантах, де вносилися органічні добрива «Біоактив», «Біопроферм» за рахунок агрофізичних, покращення властивостей грунту та його біологічної активності покращувався поживний i водний режим грунту, що забезпечило збільшенню відповідно польової схожості на 6,7-7,1 \% та виживання рослин на 4,4-4,6 \% порівняно 3 контролем. На цих варіантах висота рослин зростала на 5,9-8,2 см порівняно 3 контролем.

Результати

досліджень показали, що на всіх варіантах де вносили мінеральні та органічні добрива порівняно 3 контролем у всіх фазах росту i розвитку сої формувалася значно більша площа листкової поверхні фотосинтетичний потенціал посівів та чиста продуктивність фотосинтезу. Найбільша площа листкової поверхні рослин сої у фазу кінець цвітіння - 41,6 тис.м²/га або на 8,9 тис.м ${ }^{2} /$ га більше контролю була на варіанті, де вносили під основний обробіток грунту 10 т/га органічного добрива «Біопроферм» із збалансованим умістом тривалентного хрому та обприскували рослини сої під час 
Бунчак О. М.

вегетації рідким органічним добривом «Біохром» - 5 л/га.

$\mathrm{Ha}$ цьому

варіанті фотосинтетичний потенціал становив 2,384 млн.м² діб/га або на 0,348 млн.м ${ }^{2}$ діб/га більше контролю, чиста продуктивність фотосинтезу у фазу цвітіння становила 10,52 г/ м $^{2}$ на добу або на 0,84 г/м² на добу більше контролю.

Урожайність сої є результатом взаємодії всіх морфо-фізіологічних ознак, що визначають особливості росту і розвитку рослин у ценозі в умовах зовнішнього середовища (кліматичні умови, система удобрення та ін.).

Експериментальними та виробничими дослідженнями встановлено вплив органічних добрив «Біопроферм» та рідкого органічного добрива «Біохром» із збалансованим умістом тривалентного хрому на продуктивність посівів сої і на вміст в зерні сої $\mathrm{C}^{+3}$.

За результатами досліджень встановлено, що органічні добрива «Біопроферм» i рідке органічне добриво «Біохром» мали позитивний вплив на агрохімічні та агрофізичні показники грунту, його біологічну активність, на ріст й розвиток рослин сої, що сприяло збільшенню урожайності сої сорту Устя (табл. 2).

Тяөлнңя 2. Урожайність сої сорту Устя залежно від внесення органічних добрив, виготовлених за новітніми технологіями (середнс за 2013-2016 рр.)

\begin{tabular}{|c|c|c|c|c|c|c|c|}
\hline \multirow{3}{*}{ Варіант } & \multicolumn{4}{|c|}{$\begin{array}{c}\text { Врожайність за роками, } \\
\text { т/га }\end{array}$} & \multirow[t]{3}{*}{$\begin{array}{l}\text { Середнє } \\
\text { за } 4 \text { роки }\end{array}$} & \multicolumn{2}{|c|}{$\begin{array}{c} \pm \text { до } \\
\text { контролю }\end{array}$} \\
\hline & \multirow{2}{*}{$\begin{array}{c}201 \\
3\end{array}$} & \multirow{2}{*}{$\begin{array}{c}201 \\
4\end{array}$} & \multirow{2}{*}{$\begin{array}{c}201 \\
5\end{array}$} & \multirow{2}{*}{$\begin{array}{c}201 \\
6\end{array}$} & & & \\
\hline & & & & & & т/га & $\%$ \\
\hline Без добрив - контроль & 1,67 & 1,83 & 1,78 & 1,96 & 1,81 & - & - \\
\hline Внесення $\mathrm{N}_{120} \mathrm{P}_{80} \mathrm{~K}_{80}$ & 2,19 & 2,45 & 2,30 & 3,80 & 2,68 & 1,25 & 48,1 \\
\hline 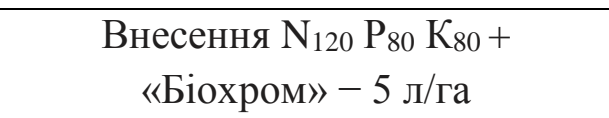 & 2,46 & 2,70 & 2,57 & 3,10 & 2,71 & 0,87 & 49,7 \\
\hline Внесення «Біоактив» - 10 т/га & 2,29 & 2,61 & 2,54 & 3,04 & 2,62 & 0,81 & 44,8 \\
\hline $\begin{array}{c}\text { Внесення «Біоактив» }-10 \text { т/га }+ \\
\text { «Біохром» }-5 \text { л/га }\end{array}$ & 2,56 & 2,84 & 2,73 & 3,38 & 2,88 & 1,07 & 59,1 \\
\hline Внесення «Біопроферм» - 10 т/га & 2,60 & 2,90 & 2,81 & 3,45 & 2,94 & 1,13 & 62,4 \\
\hline $\begin{array}{c}\text { Внесення «Біопроферм» }-10 \text { т/га } \\
+ \text { «Біохром» }-5 \text { л/га }\end{array}$ & 2,79 & 2,95 & 2,84 & 3,67 & 3,06 & 1,25 & 69,1 \\
\hline $\mathrm{HIP}_{05}$ & 0,13 & 0,12 & 0,14 & 0,16 & - & - & - \\
\hline
\end{tabular}


Бунчак О. М.

Досліджено, що органічні добрива, виготовлені за новітніми технологіями, в усі роки досліджень впливали на підвищення врожайності сої. Так, у варіанті, де під зяблеву оранку вносили органічні добрива «Біопроферм» у дозі 10 т/га та виконували позакореневе підживлення регулятором росту «Біохром» (5 л/га), в середньому за роки досліджень урожайність була на 1,25 т/га більше, ніж у контролі і на 0,18 т/га більше, ніж у варіанті 3 внесенням органічного добрива «Біоактив» у дозі 10 т/га та

Тәєднңң-3. Вплив органічних добрив на якісні показники насіння сої сорту Устя (сер. 2013-2016 рр.)

\begin{tabular}{|c|c|c|c|}
\hline \multirow[t]{2}{*}{ Варіант } & \multicolumn{2}{|c|}{ Уміст, \% } & \multirow{2}{*}{$\begin{array}{c}\text { Уміст тривалентного } \\
\text { хрому в насінні сої мг/кг }\end{array}$} \\
\hline & білка & жиру & \\
\hline Без добрив - контроль & 41,2 & 19,1 & 0,515 \\
\hline Внесення $\mathrm{N}_{120} \mathrm{P}_{86} \mathrm{~K}_{86}$ & 41,4 & 19,4 & 0,522 \\
\hline $\begin{array}{c}\text { Внесення } \mathrm{N}_{120} \mathrm{P}_{86} \mathrm{~K}_{86}+ \\
\text { «Біохром»- } 5 \text { л/га }\end{array}$ & 41,6 & 19,5 & 0,605 \\
\hline Внесення «Біоактив» - 10 т/га & 41,5 & 19,6 & 0,617 \\
\hline $\begin{array}{c}\text { Внесення «Біоактив» - } 10 \text { т/га + } \\
\text { «Біохром»- } 5 \text { л/га }\end{array}$ & 41,6 & 19,8 & 0,703 \\
\hline Внесення «Біопроферм» - 10 т/га & 47,8 & 19,7 & 0,843 \\
\hline $\begin{array}{c}\text { Внесення «Біопроферм»- } 10 \text { т/га + } \\
\text { «Біохром»- } 5 \text { л/га }\end{array}$ & 48,2 & 20,3 & 1,102 \\
\hline
\end{tabular}

Результати показали, що на варіанті де вносили під основний обробіток по 10 т/га органічного добрива «Біопроферм» уміст в зерні сої білка становив 47,8 \% або на 6,6 \% більше, ніж жиру $19,7 \%$ або на 1,2 \% більше, тривалентного хрому 0,843 мг/кг або на 0,268 мг/кг більше контролю, обприскуванням рідким органічним добривом «Біохром» в дозі 5 л/га під час вегетації рослин культури.

У цьому варіанті найвища врожайність сої сорту Устя на зерно (3,67 т/га) була найсприятливішого 2016 року, а найнижча (2,84 т/га) найменш сприятливого за кліматичними умовами 2013 року.

Дослідженнями встановлено, що органічні добрива виготовлені за новітніми технологіями значно впливали на якісні показники зерна та збільшили уміст $\mathrm{Cr}^{+3}$ в зерні сої сорту Устя (табл. 3). 
Бунчак О. М.

1,102 мг/кг або на 0,527 мг/кг більше контролю.

Висновки. Таким чином, на основі виконаного нами дослідження встановлено, що застосування органічних добрив «Біопроферм», «Біоактив» та «Біохром» позитивно впливає на ріст й розвиток рослин сої сорту Устя протягом усього періоду їх вегетації. Тому в адаптивноландшафтних технологіях

\section{Список використаних джерел}

1. Бунчак O.M. Особливості формування врожаю сої умістом залежно від застосування органічних добрив, виготовлених за новітніми технологіями. : Вісник Дніпропетровського державного аграрно-економічного факультету. : Дніпро 2017, № 3. С. 36-40.

2. Хром у живленні тварин: монографія / Р.Я. Іскра, В.В. Влізло, Р.С. Федорук, Г.Л. Антоняк. : К.: Аграр. наука, 2014. С. 3-35.

3. Anderson R.A. Nutritional factors influencing the glucose/insulin system: Chromium. : Journal of American College Nutrition. 1997. V. 16. P. 404-410.

4. Сологуб Л. І. Антоняк Г. Л., Бабич Н. О. Хром в організмі людини і тварин : Львів: Свросвіт, 2007. 128 c.

\section{5. Каталымов}

M. B.

Микроэлементы и удобрения. М.: Химия, 1965. 330 с.[Гигиена окружающей среды // Под вирощування сої слід вносити органічні добрива «Біопроферм» в дозі 10 т/га з умістом тривалентного хрому (540 мг/кг) та обприскувати рослини рідким органічним добривом «Біохром» 5 л/га під час вегетації, що забезпечить підвищення врожайності на 62,4$69,1 \%$ і отримання екологічно чистої продукції 3 умістом необхідної кількості тривалентного хрому.

редакцией Г.И. Сидоренко М.: Медицина, 1985 С. 140-146.

6. Samantary S., Rout G.R., Das P. Role of chromium on plant growth and matabolim // Acta Physiol. Plantarum, 1998. V. 20. № 2. P. 201212.

$$
\text { 7. Шувар }
$$

I.

A.,

Сендецький В. М., Бунчак О. М., Гнидюк В. С., Тимофійчук О. Б. Виробництво та використання органічних добрив ІваноФранківськ: Симфонія форте, 2015. 596 c.

8. Патент на корисну модель № 85187 „Спосіб отримання органічних добрив нового покоління із збалансованим вмістом тривалентного хрому" / О. М. Бунчак, I. П. Мельник, Н. М. Колісник, В. С. Гнидюк. бюл. №21, 2013.

9. Доспехов Б.А. Методика полевого опыта. : M. : Агропромиздат, 1985. С. 10-75.

10. Бабич А. О.

Бахмат M. I., Бахмат О. М. Соя - 
Бунчак О. М.

агроекологічні

основи

вирощування, переробки i

використання. : Київ : Медобори 2013. С. 5-40.

\section{1. Ничипорович}

A. A. Строганова Л. Е., Власова М. П. Фотосинтетическая деятельность растений в посевах. : Л. Изд-во AHCCCP, 1986. 68 c.

\section{References}

1. Bunchak O.M. (2017).

Osoblyvosti formuvannya vrozhayu soyi umistom zalezhno vid zastosuvannya orhanichnykh dobryv, vyhotovlenykh za novitnimy tekhnolohiyamy [Features of the formation of soybean crop contents depending on the application of organic fertilizers, manufactured according to the latest technologies] Visnyk

Dnipropetrovs'koho derzhavnoho ahrarnoekonomichnoho fakul'tetu. Dnipro, no 3. P. 36-40.

2. Iskra R.Ya., Fedoruk R.S., Antonyak H.L. (2014). Khrom u zhyvlenni tvaryn: monohrafiya [Chromium in animal nutrition: monograph]. K.: Ahrar. nauka, 3-35.

3. Anderson R.A. (1997). Nutritional factors influencing the glucose/insulin system: Chromium [Nutritional factors influencing the glucose/insulin system: Chromium]. Journal of American College Nutrition. - V. 16. 404-410.

4. Solohub L. I., Antonyak H. L., Babych N. O. (2007). Khrom v orhanizmi lyudyny i tvaryn
[Chromium in the human body and animals]. L'viv: Yevrosvit, 128.

5. Katalomov M.V. (1985). Mykroэlementы y udobrenyya [Microelements and fertilizers] // M.: Khymyya, 1965. 330 s.[Hyhyena okruzhayushchey sredы // Pod redaktsyey H.Y. Sydorenko M.: Medytsyna. P. 140-146.

6. Samantary S., Rout G.R., Das P. (1998). Role of chromium on plant growth and matabolim [Role of chromium on plant growth and matabol] Acta Physiol. Plantarum. V. 20. no 2. P. 201-212.

7. Shuvar I. A., Sendets'kyy V. M., Bunchak O. M., Hnydyuk V. S., Tymofiychuk O. B. (2015). Vyrobnytstvo ta vykorystannya orhanichnykh dobryv [Production and use of organic fertilizers]. IvanoFrankivs'k: Symfoniya forte. 596.

8. Bunchak O. M., Mel'nyk I. P., Kolisnyk N. M., Hnydyuk V. S. (2013). ,Sposib otrymannya orhanichnykh dobryv novoho pokolinnya iz zbalansovanym vmistom tryvalentnoho khromu" ["A method for obtaining organic fertilizers of a new generation with a balanced content of trivalent chromium"]. Patent na korysnu model' no 85187 . byul. no 21.

9. Dospekhov B.A. (1985). Metodyka polevoho opыta. [Field experiment technique] M.: Ahropromyzdat. 10-75 p.

10. Babych A. O., Bakhmat M. I., Bakhmat O. M. (2013). Soya - 
Бунчак О. М.

ahroekolohichni

osnovy

vyroshchuvannya, pererobky i

vykorystannya

[Soybean

agroecological bases of cultivation, processing and use] Kyyiv : Medobory. - 5-40 s.

\section{УРОЖАЙНОСТЬ И КАЧЕСТВЕННЫЕ}

ПОКАЗАТЕЛИ ЗЕРНА СОИ В ЗАВИСИМОСТИ ОТ ПРИМЕНЕНИЯ

ОРГАНИЧЕСКИХ УДОБРЕНИЙ

СО СБАЛАНСИРОВАННЫМ СОДЕРЖАНИЕМ

ТРЕХВАЛЕНТНОГО ХРОМА

\section{А. М. Бунчак}

Аннотация. Представлены результать влияния органических удобрений «Биопроферм», «Биоактиво» $u$ «Биохром» со сбалансированным содержанием трехвалентного

хрома изготовленных методами соответственно биологической ферментацуии и кавитациии на урожайность и качественные показатели зерна сои сорта Устя в условиях Западной Лесостепи.

Целью исследования было изучить влияние органических удобрений изготовленных по новейшим технологиям на рост $u$ развитие растений и урожайность сои сорта Устья в условиях Западной Лесостепи.

Полевые и лабораторные исследования выполнены в условиях западной Лесостепи в течение 2013-2016 г2. на опытном поле Подольского государственного аграрно-технического

университета. Почва участка - чернозем

опьтнного типичный
11. Nychyporovych A.A., Strohanova L.E., Vlasova M.P. (1986). Fotosyntetycheskaya deyatel'nost' rastenyy $\mathrm{V}$ posevakh [Photosynthetic activity of plants in crops] L. Yzd-vo ANSSSR. 68 s.

тяжелосуглинистого

гранулометрического состава.

Агротехника вырашивания сои общепринятая для условий западной Лесостепи Украиньл. Сопутствуюшие исследования $u$ наблюдения выполнено по общепринятым методикам.

Установлено, что во всех вариантах, где вносились органические удобрения "Биоактив», «Биопроферм», за счет улучшения агрофизических, агрохимических свойств почвы и ее биологической активности, улучшался ее питательный $u$ водный, что обеспечило увеличение полевой всхожести семян на 6,7-7, $1 \%$, выюживаемости растений на 4,4-4,6\%, a также высоте растений на 5,9-8,2 см по сравнению с контролем.

Наибольшая плошадь листовой поверхности растений сои в фазу конеи иветения - 41,6 тыс.м²/га или на 8,9 mыс.м. ${ }^{2} / 2$ больше контроля была на варианте, где вносили под основную обработку почвы $10 \mathrm{~m} / 2$ a органического удобрения «Биопроферм» co сбалансированным содержанием трехвалентного хрома

$u$
опрыскивали растения сои в период вегетации жидким органическим удобрением «Биохром» - 5 л/га.

$$
\text { На этом }
$$

варианте фотосинтетический потенцииал 
Бунчак О. М.

составлял 2,384 млн.м² суток/га или на 0,348 млн.м ${ }^{2}$ суток/га больше контроля, чистая продуктивность фотосинтеза в фазу цвветения составила $10,52 \mathrm{2} / \mathrm{m}^{2}$ в сутки или на 0,84 г/м в в сутки больше контроля.

Доказано, что органические удобрения, изготовленные по новейшим технологиям, во все годы исследований влияли на повышение урожайности сои. Так, в варианте, где под зяблевую вспашку вносили органические удобрения «Биопроферм» в дозе $10 \mathrm{~m} / \mathrm{za} u$ выполняли внекорневую подкормку жидким органическим удобрением «Биохром» (5 л / га), в среднем за годы исследований урожайность была на 1,25 m/2а больше, чем в контроле и на 0,18 m/2а больше, чем в варианте с внесением органического «Биоактив» в опрыскиванием органическим удобрения дозе $10 \mathrm{~m} / 2 \mathrm{a} u$ жидким «Биохром» в дозе $5 \mathrm{r} / 2$ в в период вегетации растений культуры.

Ключевые слова: соя, рост и развитие растений, урожайность, качество зерна

\section{YIELD AND QUALITY INDICATORS OF SOYBEAN GRAIN DEPENDING ON THE APPLICATION OF ORGANIC FERTILIZERS WITH BALANCED CONTENT OF TRIVALENT CHROMIUM}

\section{A. M. Bunchak}

Abstract. The results of the influence of organic fertilizers «Bioproerm», "Bioactive» and «Biochrom» with balanced content of trivalent chromium produced by methods of biological fermentation and cavitation on yields and quality indices of soybeans of the Ustyug variety in the conditions of the Western Forest-steppe are highlighted.

The aim of the study was to investigate the influence of organic fertilizers produced on the basis of the latest technologies on the growth and development of plants and the yield of Soybean varieties of the Usty in the conditions of the Western ForestSteppe.

Field and laboratory investigations were carried out in the conditions of the western forest-steppe during 2013-2016 at the experimental field of the Podilsky State AgrarianTechnical University. The soil of the experimental site - black earth is a typical heavy-granular granulometric composition.

Soybean cultivator is generally accepted for the conditions of the western forest-steppe Ukraine. Concomitant studies and observations are performed according to generally accepted techniques. It has been established that in all variants where organic fertilizers "Bioactive» and «Bioproerm» were introduced due to improvement of agrophysical, agrochemical properties of the soil and its biological activity, the nutrient and water regime of the soil improved, which resulted in an increase in the field similarity by 6.7-7, $1 \%$ and plant survival by 4.4-4.6\% compared with control. In these variants, plant height increased by 5.9-8.2 cm compared to control.

The largest area of the leaf surface of soybean plants in the phase of the end of flowering - 41.6 thousand 
Бунчак О. М.

$\mathrm{m}^{2} / \mathrm{ha}$ or 8.9 thousand $\mathrm{m}^{2} / \mathrm{ha}$ more control was in the version where they introduced under the basic cultivation of soil 10 tons per hectare of organic fertilizer «Bioproerm» with balanced content of tri-chromium and sprayed soy plants during vegetation with liquid organic fertilizer «Biochrom» $5 \mathrm{l} / \mathrm{ha}$.

In this variant, the photosynthetic potential was 2.384 million $\mathrm{m}^{2} / \mathrm{ha}$ or 0.348 million $\mathrm{m}^{2} /$ ha more control, the net productivity of photosynthesis in the flowering phase was $10.52 \mathrm{~g} / \mathrm{m}^{2}$ per day or $0.84 \mathrm{~g} / \mathrm{m}^{2}$ per day more control.

It was investigated that organic fertilizers, manufactured according to the latest technologies, in all years of research have had an effect on increasing the yield of soybeans. So, in the version, where organic fertilizers were introduced into the "Bioproerm》 at a dose of $10 \mathrm{t} / \mathrm{ha}$, and subjected to foliar fertilization with "Biochrom» liquid liquid fertilizer (5 l/ha), on the average over the years the yield was $1.25 \mathrm{t}$ /ha more than in the control and by $0.18 \mathrm{t}$ /ha more than in the variant with the introduction of organic fertilizer «Bioactive» at a dose of 10 t/ha and spraying with liquid organic fertilizer «Biochrom» in a dose of 5 l/ha during the vegetation plants of culture.

Key words: soybean, plant growth and development, yield, quality of grain 